\title{
KAJIAN EKTRAKSI GELATIN DARI TULANG IKAN KATOMBO (Selar crumenopthalmus)
}

\author{
[The Study of Gelatin Extraction from Katombo Fish Bone (Selar crumenopthalmus)] \\ Nurhaeni ${ }^{1 *}$, Rian S. Rauf ${ }^{1}$, Jaya Hardi ${ }^{1}$ \\ 1) Jurusan Kimia, Fakultas MIPA, Universitas Tadulako \\ Jl. Soekarno Hatta, Kampus Bumi Tadulako Tondo Palu, Telp. 0451- 422611 \\ *)Corresponding author: eni_kimia64@yahoo.co.id \\ Diterima 5 Maret 2018, Disetujui 30 April 2018
}

\begin{abstract}
The study of gelatin extraction from Katombo fish bone has been carried out. This study intends to determine the effect of soaking time and ratio of katombo fish with $9 \%$ citric acid solution to yield and quality of the produced katombo fish gelatin. The results showed that the best soaking time was 60 hours with yield, ash content, moisture content, viscosity, and gel strength of $6.442 \%, 4.50 \%, 8.70 \%$, $2.93 \mathrm{cP}$, and $44.40 \mathrm{~mm} / \mathrm{kg} . \mathrm{s}$, respectively. The best ratio between katombo fishbone with $9 \%$ citric acid solution was $1: 4(\mathrm{w} / \mathrm{v})$ with yield, ash content, moisture content, viscosity, and gel strength of $6.938 \%, 3.70 \%, 8.70 \%, 2.93 \mathrm{cP}$, and $44.30 \mathrm{~mm} / \mathrm{kg}$, respectively.
\end{abstract}

Keywords: Gelatin, Selar crumenopthalmus, extraction, viscosity, gel strength

\begin{abstract}
ABSTRAK
Penelitian ini bermaksud untuk mengetahui waktu perendaman dan rasio tulang ikan katombo dengan larutan asam sitrat $9 \%$ terhadap rendemen dan mutu gelatin tulang ikan katombo yang dihasilkan. Hasil penelitian menunjukkan waktu terbaik pada perendaman tulang ikan katombo adalah 60 jam dengan rendemen $6,442 \%$, kadar abu 4,50\%, kadar air 8,70\%, viskositas $2,93 \mathrm{cP}$ dan kekuatan gel $44,40 \mathrm{~mm} / \mathrm{kg}$.s. Rasio terbaik antara tulang ikan katombo terhadap larutan asam sitrat $9 \%$ adalah $1: 4(\mathrm{~b} / \mathrm{v})$ dengan rendemen $6,938 \%$, kadar abu 3,70\%, kadar air 8,70\%, viskositas 2,93 cP dan kekuatan gel sebesar $44,30 \mathrm{~mm} / \mathrm{kg} . \mathrm{s}$.
\end{abstract}

Kata kunci : Gelatin, ikan katombo, ekstraksi, viskositas, kekuatan gel 


\section{LATAR BELAKANG}

Gelatin merupakan sutau jenis protein yang diperoleh melalui hidrolisis kolagen, yang merupakan protein utama yang ditemukan di kulit dan tulang. Gelatin telah banyak digunakan dalam bahan makanan, industri, farmasi, kesehatan, kosmetik dan industri fotografi karena sifat fungsionalnya yang unik.

Pemanfaatan gelatin di industri pangan digunakan sebagai bahan penstabil (stabilizer), pengikat (binder agent), pembentuk gel (gelling agent), pengemulsi (emulsifier), peningkat viskositas (viscosity agent), dan perekat (adhesive). Industri non-pangan yang menggunakan gelatin meliputi industri farmasi (sebagai pembuat kapsul, pengikat tablet dan pastilles, surgical powder, plasma expander, dan mikroenkapsulasi), industri fotografi (sebagai pengikat bahan peka cahaya) dan industri kertas (sebagai sizing paper) (Schrieber dan Gareis, 2007).

Senyawa gelatin umumnya dibuat dari tulang hewan mamalia, seperti sapi dan babi. Produksi gelatin umumnya berasal dari kulit babi hingga 46\%, kulit sapi $29 \%$, tulang sapi $23 \%$, dan sumber lain 1,5\% (Karim dan Bhat, 2009). Gelatin dari tulang sapi dan babi menimbulkan polemik bagi masyarakat Indonesia baik itu dari aspek religi maupun kesehatan. Dari aspek religi, masyarakat Indonesia yang beragama Islam tidak mengkonsumsi bahan makanan dari babi, dipihak lain masyarakat yang beragama
Hindu tidak mengkonsumsi bahan dari sapi, sedangkan dari aspek kesehatan banyak dihindari karena penyakit sapi gila.

Gelatin dari limbah ikan adalah alternatif lain yang sangat potensial untuk menggantikan gelatin dari mamalia. Karena selain halal bagi semua agama, gelatin dari limbah ikan juga sangat ekonomis jika diarahkan untuk mengolah sisa hasil industri-industri pengolahan ikan. Kajian ekstraksi gelatin dari tulang dan kulit ikan telah banyak dilakukan diantaranya dari ikan bandeng (Fatimah, 2008); ikan tuna (Amiruldin, 2007); ikan kakap merah (Kusumawati, 2008); ikan kakap putih (Dian et al., 2012); ikan kacikaci (Tazwir et al., 2007); ikan nila (Junianto et al., 2006); ikan pari (Karlina dan Atmaja, 2010); ikan anggoli (Putri, 2013) dan ikan gabus (Wulandari et al., 2013). Kajian ekstraksi gelatin dari tulang ikan katombo belum pernah dilakukan, oleh karena itu perlu dilakukan penelitian mengenai kajian ektraksi gelatin dari tulang ikan katombo guna memberikan informasi tambahan mengenai prospek dan perkembangan gelatin ikan dimasa mendatang.

Kualitas gelatin antara lain dipengaruhi oleh kekuatan gel, viskositas dan titik leleh. Parameter kualitas tersebut sangat dipengaruhi oleh faktor konsentrasi larutan gelatin, kandungan garam, waktu dan suhu pemanasan, dan $\mathrm{pH}$. Selain itu, faktor dalam proses ektraksi gelatin juga mempengaruhi sifat gelatin, seperti proses demineralisasi. 
Proses ini dapat berlangsung dalam larutan asam dengan konsentrasi tertentu. Kadar asam yang terlalu tinggi dapat mengakibatkan protein kolagen tidak dapat diubah menjadi gelatin (Jannah, 2007). Penentuan konsentrasi asam terbaik telah banyak dilakukan, namun pengaruh rasio antara berat tulang terhadap volume asam belum pernah dilakukan.

Faktor lain yang mempengaruhi kualitas gelatin, seperti kadar protein, dan kekuatan gel adalah waktu perendaman (Irawan et al., 2006). Lama perendaman terbaik untuk setiap species tulang berbeda, hal itu dapat dilihat dari penelitian-penelitian sebelumnya, diantaranya penelitian Fatimah (2008) yang meyebutkan bahwa lama perendaman 48 jam dalam asam sitrat sangat efektif untuk produksi gelatin. Sementara itu, lama perendaman terbaik pada ikan anggoli dan hiu masing-masing adalah 24 jam (Putri, 2013) dan 36 jam (Irawan et al., 2006). Maka dari itu, perlu dilakukan pencarian waktu perendaman terbaik gelatin dari tulang ikan katombo.

\section{METODE PENELITIAN}

\section{Bahan dan Peralatan}

Bahan yang digunakan adalah ikan katombo yang ada di Sulawesi Tengah, larutan asam sitrat 9\%, kertas saring biasa, alumunium foil, tisue dan aquades.

Peralatan yang digunakan untuk penelitian waterbath shaker, rotary vakum evaporator, viskometer Ostwald, tanur pengabuan, dan penetrometer.

\section{Prosedur Kerja}

\section{Penyiapan tulang ikan}

Tulang ikan katombo dipisahkan dari daging dan kulitnya, lalu dibersihkan dengan air. Tulang ikan selanjutnya didegreasing dalam air pada suhu $70-80^{\circ} \mathrm{C}$ selama 10 menit sambil diadukaduk, kemudian dibersikan dari sisa lemak. Tulang ikan ditiriskan dan dikering anginkan, kemudian dipotong kecil-kecil $(1-2 \mathrm{~cm})$.

\section{Ekstraksi gelatin}

Potongan tulang ikan direndam dalam larutan asam sitrat 9\% dengan rasio tulang terhadap larutan asam 1:2, 1:3, 1:4, 1:5, $1: 6(\mathrm{~b} / \mathrm{v})$ selama $24,36,48,60$, dan 72 jam. Setelah itu, tulang dicuci dengan air mengalir sampai pH-nya netral. Ekstraksi dilakukan dengan aquades (rasio 1:3 (b/v)) dalam waterbath shaker pada suhu $70^{\circ}-80^{\circ} \mathrm{C}$ selama 8 jam, kemudian disaring dan dipekatkan dengan evaporator. Cairan pekat gelatin dituang ke dalam wadah plastik dan disimpan dalam oven pada suhu $50^{\circ} \mathrm{C}$ selama 24 jam. Gelatin kering yang dihasilkan ditentukan rendemen, kadar air, kadar abu, viskositas, dan kekuatan gel.

\section{HASIL DAN PEMBAHASAN}

\section{Waktu Perendaman Tulang Ikan Katombo.}

\section{Rendemen}

Efisiensi suatu bahan baku layak dijadikan sebagai gelatin dilihat dari hasil 
rendeman yang dihasilkan. Rendemen gelatin tertinggi dari tulang ikan katombo diperoleh pada waktu perendaman 60 jam dengan nilai 6,44\% (Gambar 1).

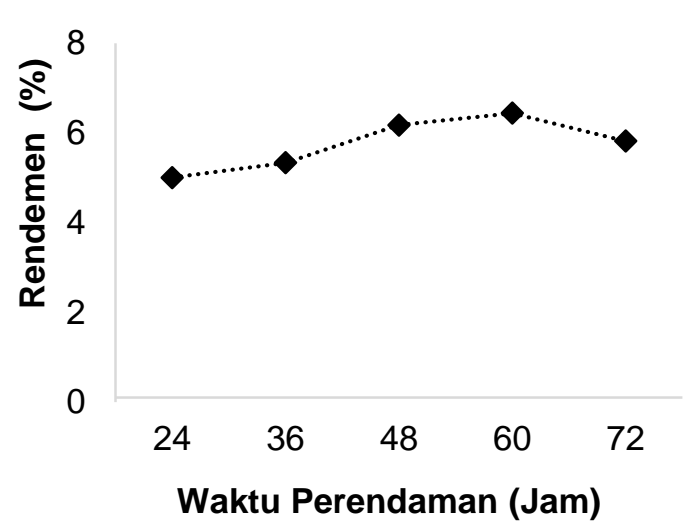

Gambar 1 Rendemen rata-rata gelatin tulang ikan katombo pada berbagai waktu perendaman.

Rendeman gelatin yang dihasilkan cenderung meningkat seiring dengan penambahan waktu perendaman. Hal ini terjadi karena waktu perendaman yang lebih lama akan mengakibatkan waktu kontak semakin lama antara tulang dan asam sitrat, sehingga akan semakin banyak kolagen yang terbebas dari kalsium tulang. Terbebasnya kolagen dalam tulang mempermudah dalam proses konversi kolagen menjadi gelatin (Fatimah, 2008). Semakin banyak kolagen bebas yang diperoleh maka akan semakin banyak gelatin yang dihasilkan. Tetapi pada waktu perendaman 72 jam, rendeman sedikit menurun. Hal ini disebabkan karena kolagen mengalami proses hidrolisis menjadi gelatin yang larut dalam asam sehingga mengurangi kadar rendemen yang dihasilkan Fatimah (2008).

\section{Kadar abu}

Gelatin tulang ikan katombo memiliki kadar abu terendah 3,8\% pada waktu perendaman 72 jam (Gambar 2).

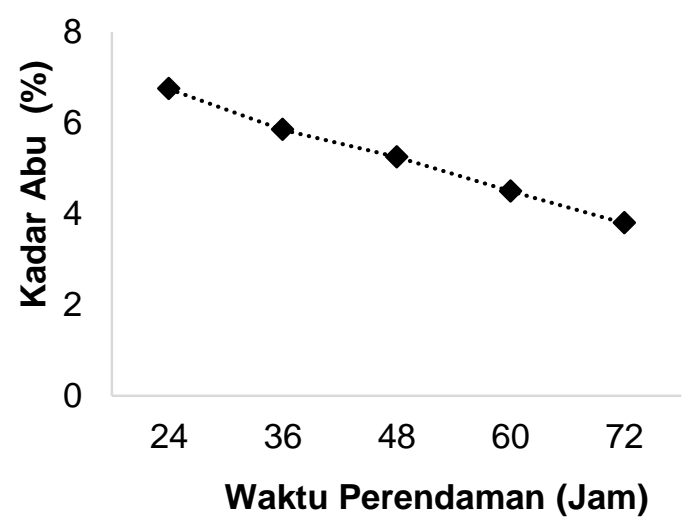

Gambar 2 Grafik kadar abu rata-rata gelatin tulang ikan katombo pada berbagai waktu perendaman.

Kadar abu yang dihasilkan mengalami penurunan disetiap waktu perendaman, yaitu dari $6,75 \%$ hingga $3,8 \%$. Hal ini disebabkan karena semakin lama waktu perendaman maka semakin banyak mineral yang diikat oleh larutan asam sitrat, akibatnya jumlah abu dalam tulang mengalami penurunan. Fatimah (2008) menyatakan bahwa selama perendaman tulang dalam asam sitrat, akan terjadi demineralisasi dimana kalsium tulang dalam bentuk kalsium fosfat diikat oleh asam sitrat menjadi kalsium sitrat. Bertambahnya waktu perendaman menyebabkan kesempatan asam dan tulang untuk saling berinteraksi semakin panjang. Endapan putih yang terbentuk setelah perendaman merupakan kalsium yang terikat pada gugus karbonil asam sitrat. 


\section{Kadar air}

Jumlah air sangat mempengaruhi ketahanan dan kesegaran suatu bahan. Kadar air gelatin terendah gelatin tulang ikan katombo diperoleh paa waktu perendaman 60 jam (Gambar 3).

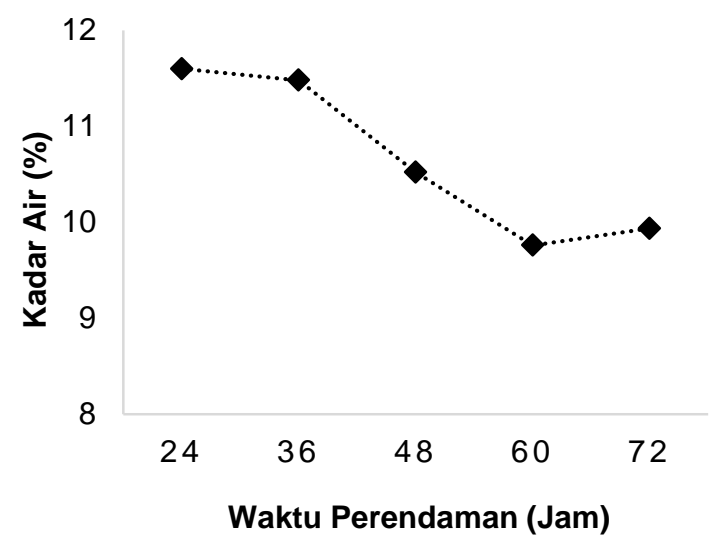

Gambar 3 Grafik kadar air rata-rata gelatin tulang ikan katombo pada berbagai waktu perendaman.

Kadar air gelatin yang dihasilkan berkisar 9,76 \% sampai 11,60 \%. Kadar air gelatin tulang ikan katombo ini telah memenuhi standar SNI yakni maksimum $16 \%$. Kadar air gelatin tulang ikan katombo juga lebih rendah dari gelatin komersial $11,70 \%$.

\section{Viskositas}

Viskositas merupakan salah satu sifat fisik gelatin yang cukup penting selain kekuatan gel. Viskositas tertinggi 2,8 cP didaptkan pada waktu perendaman 72 jam (Gambar 4).

Nilai viskositas gelatin meningkat dengan naiknya waktu perendaman. Hal ini disebabkan waktu perendaman yang lama akan memaksimalkan proses hidrolisis kolagen. Semakin maksimal hidrolisis kolagen maka akan semakin banyak asam amino berantai panjang yang dihasilkan sehingga meningkatkan nilai viskositas. Tazwir et al. (2007) melaporkan bahwa berat molekul tinggi dan rantai asam amino yang panjang dapat meningkatkan viskositas gelatin.

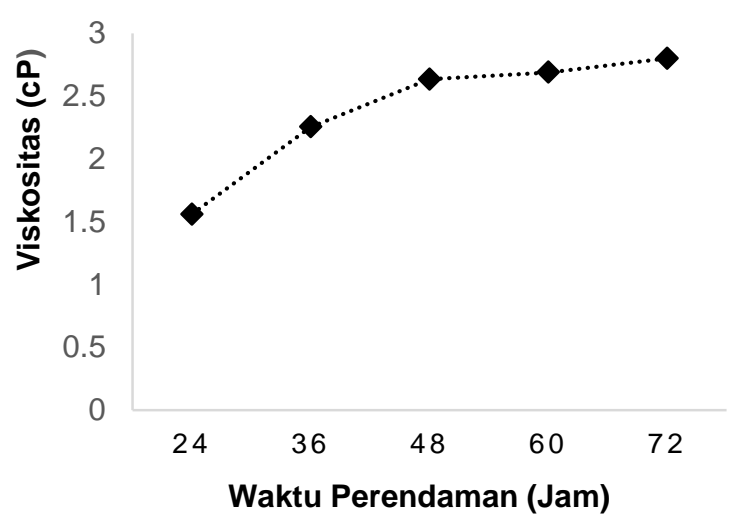

Gambar 4. Grafik nilai viskositas rata-rata gelatin tulang ikan katombo pada berbagai waktu perendaman.

Viskositas yang meningkat juga dipengaruhi oleh kadar abu gelatin yang semakin kecil (Lestari (2005) dalam Kurniawan (2009)). Gugus fungsi dari gelatin, seperti $\mathrm{OH}, \mathrm{COOH}$ dan $\mathrm{NH}_{2}$ dapat berikatan dengan mineral sehingga interaksi gelatin dengan larutan menjadi semakin sedikit, sehingga distribusi molekul gelatin semakin cepat dan nilai viskositas menjadi turun. Artinya semakin rendah abu dalam gelatin maka semakin kecil peluang gugus gelatin untuk berikatan dengan gugus mineral yang berupa abu, sehingga distribusi molekul gelatin semakin lambat yang berefek pada peningkatan nilai viskositas.

\section{Kekuatan gel}

Gelatin memiliki kemampuan mengubah cairan menjadi padatan atau sol menjadi gel yang reversible sehingga 
parameter kekuatan gel menjadi ukuran penting pada penentuan kualitas gelatin (Prihardhani dan Yunianta, 2015). Kekuatan gel ditentukan menggunakan penetrometer dengan menganalisis waktu penekanan sampel yang mengandung gelatin $5 \%$. Kekuatan gel dengan nilai terendah adalah yang memiliki kualitas gel terbaik, karena waktu penetrasi menjadi acuan dalam penentuan nilai kekutan gel. Penetrasi yang lama menghasilkan angka kekuatan gel kecil, begitu juga sebaliknya (Fatimah, 2008).

Nilai kekuatan gel dari gelatin ikan katombo cenderung menurun seiring dengan naiknya waktu perendaman (Gambar 5). Hal ini terjadi karena semakin lama perendaman maka akan semakin cepat proses hidrolisis kolagen, meningkatnya jumlah kolagen yang terhidrolisis akan menghasilkan banyak rantai polipeptida yang panjang. Semakin besar panjang rantai, maka semakin besar berat molekul dan semakin tinggi kekuatan gelnya (Junianto et al., 2006).

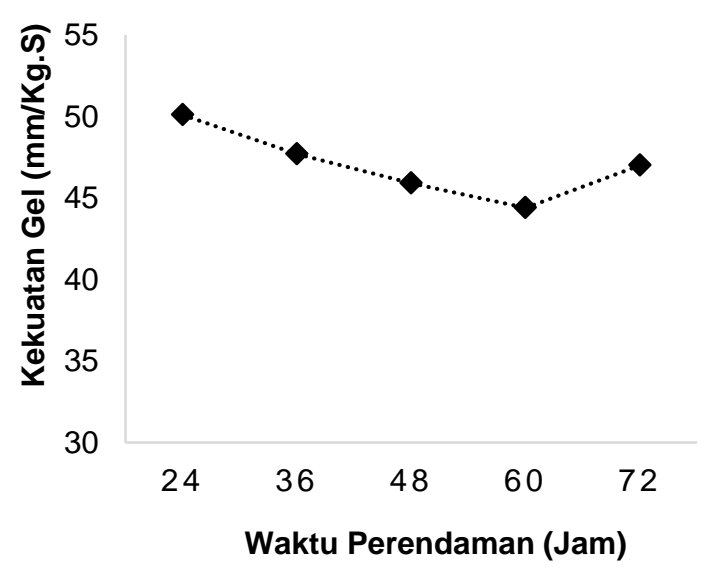

Gambar 5 Grafik nilai kekuatan gel rata-rata gelatin tulang ikan katombo pada berbagai waktu perendaman.
Berdasarkan hasil analisis parameter gelatin dan uji statistik, maka dapat ditentukan waktu perendaman terbaik tulang ikan katombo dalam larutan asam sitrat $9 \%$ adalah 60 jam dengan rendemen 6,442 \%, kadar abu 4,50\%, kadar air 9,76\%, viskositas 2,69 cP, dan kekuatan gel $44,40 \mathrm{~mm} / \mathrm{kg} . \mathrm{s}$.

\section{Rasio Tulang Ikan Katombo terhadap Volume Asam Sitrat $9 \%$.}

\section{Rendemen}

Penggunaan rasio 1:4 mampu menghasilkan rendemen gelatin tertinggi, yaitu 6,94\% (Gambar 6). Rendemen gelatin tulang ikan katombo pada variasi rasio berkisa antara 5,064\% sampai $6,938 \%$.

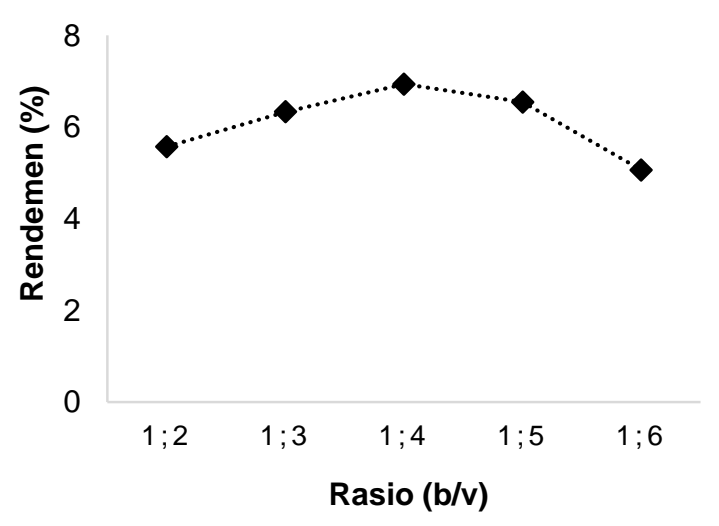

Gambar 6. Grafik nilai rendemen rata-rata gelatin tulang ikan katombo pada berbagai rasio

Nilai rendemen gelatin terus meningkat dengan bertambahnya larutan asam, namun pada rasio $1: 5$ rendemen mengalami penurunan. $\mathrm{Hal}$ ini terjadi karena pada perlakuan tersebut kolagen telah terhidrolisis akibat peningkatan jumlah konsentrasi $\mathrm{H}^{+}, \quad$ sehingga mengurangi kadar rendemen yang dihasilkan. Santoso (2001) menyatakan 
bahwa meningkatnya konsentrasi $\mathrm{H}^{+}$ mempercepat laju hidrolisis kolagen, namun konsentrasi $\mathrm{H}^{+}$yang berlebih mengakibatkan terjadi denaturasi kolagen terhidrolisis, artinya kolagen terhidrolisis (pengembangan kolagen) semakin bertambah sehingga terjadi penyebaran kolagen dalam larutan asam.

\section{Kadar abu}

Gelatin dengan kadar abu rendah adalah gelatin yang sangat baik dan lebih disukai dalam pengolahan pangan. Kadar abu yang didapatkan mengalami penurunan seiring bertambahnya rasio berat tulang terhadap volume larutan asam sitrat (Gambar 7).

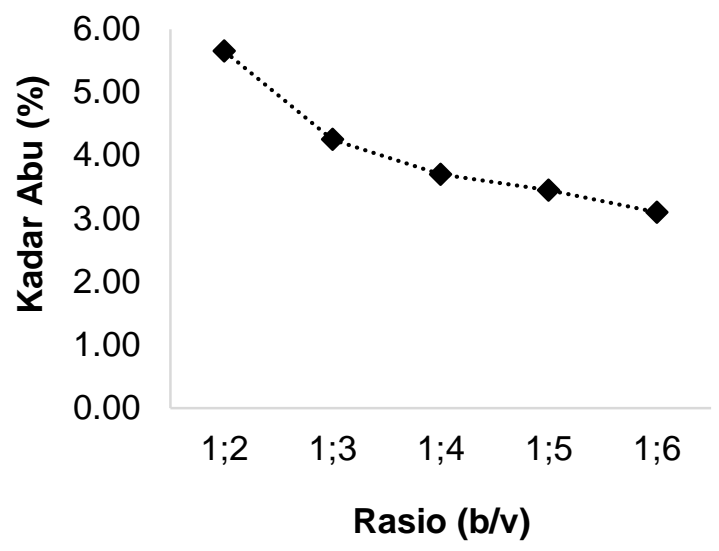

Gambar 7. Grafik kadar abu rata-rata gelatin tulang ikan katombo pada berbagai rasio.

Kadar abu yang semakin menurun diakibatkan bertambahnya volume asam, sehingga jumlah $\mathrm{H}^{+}$meningkat dalam larutan asam sitrat. Jumlah $\mathrm{H}^{+}$yang tinggi akan menyebabkan proses dimineralisasi berjalan semakin cepat, sehingga jumlah mineral-mineral yang berupa abu semakin banyak yang diikat oleh asam, dilain pihak kolagen semakin terbebas dari jeratan mineral-mineral tersebut (Fatimah, 2008). Kalsium dalam tulang ikan cakalang akan diikat oleh asam sitrat dalam bentuk kalsium sitrat.

\section{Kadar air}

Kadar air gelatin tulang ikan katombo berkisar antara 8,70\% - 9,89\% (Gambar 8). Kadar air terendah dari gelatin berada pada rasio 1:4, yaitu $8,70 \%$. Kadar air gelatin ikan katombo masih lebih baik dari gelatin komersial yakni $11,695 \%$. Hal ini menunjukkan bahwa nilai kadar air gelatin penelitian dari tulang ikan katombo sangat baik karena lebih rendah dari gelatin komersial dan juga telah memenuhui standar kadar air $16 \%$ yang diajukan SNI.

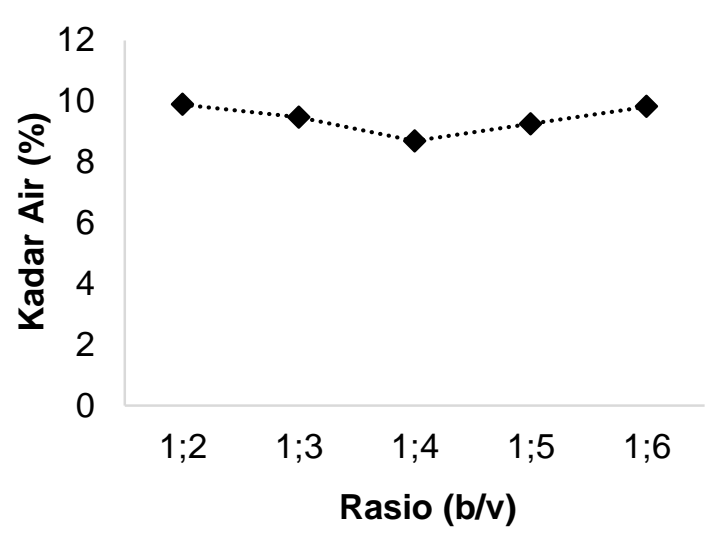

Gambar 8. Grafik kadar air rata-rata gelatin tulang ikan katombo pada berbagai rasio.

\section{Viskositas}

Penambahan volume larutan asam atau peningkatan rasio menyebabkan terjadi peningkatan nilai viskositas, hingga rasio 1:4 dengan nilai 3,13 cP (Gambar 9). Peristiswa ini terjadi karena, bertambahnya larutan asam akan menaikkan jumlah konsentrasi ion $\mathrm{H}^{+}$ 
dalam larutan asam. Santoso (2001) melaporkan bahwa peningkatan konsentrasi $\mathrm{H}^{+}$akan mempercepat laju hidrolisis kolagen menjadi gealtin, sehingga nilai viskositas meningkat.

Nilai viskositas pada perlakuan rasio 1:5 dan 1:6 mengalami penurunan karena pada konsentrasi asam yang tinggi akan terjadi hidrolisis lanjutan pada kolagen yang sudah terkonversi menjadi gelatin sehingga menyebabkan rantai asam amino menjadi lebih pendek (Tazwir et al., 2007).

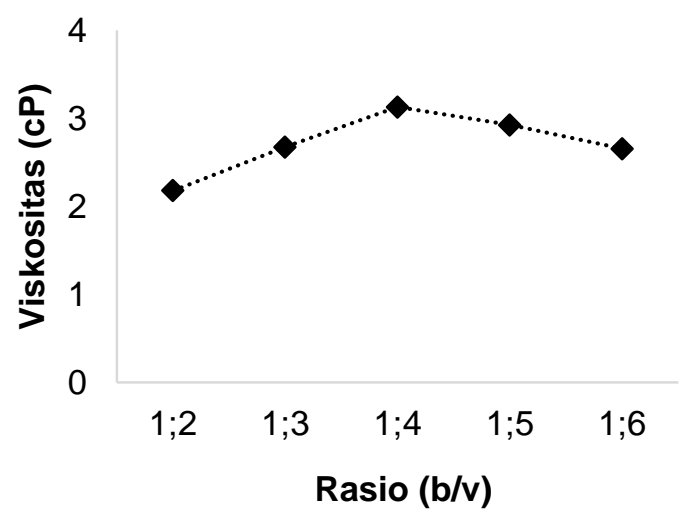

Gambar 9. Grafik nilai viskositas rata-rata gelatin tulang ikan katombo pada berbagai rasio.

\section{Kekuatan gel}

Kekuatan gel terendah dari gelatin tulang ikan katombo didapatkan pada rasio 1:4, yaitu $44,30 \mathrm{~mm} / \mathrm{Kg} . \mathrm{s}$ (Gambar 10). Kekuatan gel mangalami penurunan hingga rasio $1: 4$, tetapi pada rasio 1:5 kekuatan gel mengalami peningkatan. Hal ini terjadi karena meningkatnya konsentrasi $\mathrm{H}^{+}$dalam larutan asam, sehingga proses hidrolisis berjalan maksimal dan terbentuk untaian pendek rantai asam amino.

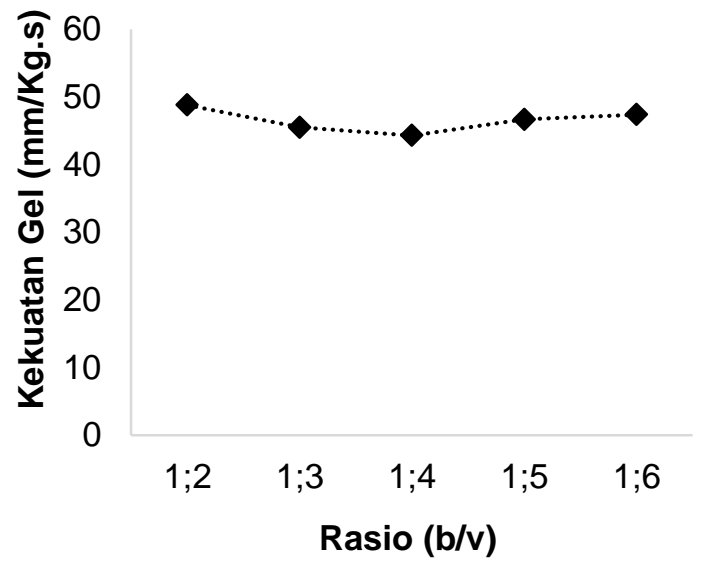

Gambar 10. Grafik nilai kekuatan gel gelatin tulang ikan katombo pada berbagai rasio rasio.

Perbandingan tulang ikan katombo terhadap asam sitrat pada rasio 1:4 merupakan perlakuan terbaik dengan rendemen rendemen $6,94 \%$, kadar abu 3,70\%, kadar air 8,70\%, viskositas 3,13 cP, dan kekuatan gel $44,30 \mathrm{~mm} / \mathrm{kg}$.s. Darwin et al. (2018) telah mengekstraksi gelatin dari tulang ikan mujair dan mendapat rasio terbaik antara tulang ikan mujair terhadap volume asam sitrat $9 \%$, yaitu 1:6 (b/v) dengan rendemen 9,44\% dan kekuatan gel $38,1 \mathrm{~mm} / \mathrm{Kg} . \mathrm{s}$.

\section{KESIMPULAN}

Waktu perendaman 60 jam dan rasio tulang terhadap asam 1:4 merupakan perlakuan terbaik dengan rendemen $6,94 \%$, kadar abu 3,70\%, kadar air 8,70\%, viskositas $3,13 \mathrm{cP}$, dan kekuatan gel $44,30 \mathrm{~mm} / \mathrm{kg} . \mathrm{s}$.

\section{DAFTAR PUSTAKA}

Amiruldin, M. 2007. Pembuatan dan Analisis Karakterisasi Gelatin dari Tulang Ikan Tuna (Thunnus albacares). [Skripsi]. Bogor: Fakultas Teknologi Pertanian, IPB. 
Darwin, Ridhay, A., dan Hardi, J. 2018. Kajian Ekstraksi Gelatin dari Tulang Ikan Mujair (Oreochromis mossambicus). KOVALEN, 4(1) : 115.

Dian, P.P., Darmawan., Erizal., dan Tjahyono. 2012. Isolasi dan Sintesis Gelatin Ikan Kakap Putih (Lates calcarifer) Berikatan Silang dengan Teknik Induksi Iradiasi Gamma. Jurnal Sains Materi Indonesia. 14(1): 40-46.

Fatimah, D. 2008. Efektivitas Penggunaa Asam Sitrat dalam Pembuatn Gelatin Tulang Ikan Bandeng (Chanos-Chanos forskal) (Kajian Variasi Konsentrasi dan Lama Perendaman). [Skripsi]. Malang: Fakultas Sains dan Teknologi, Universitas Islam Negeri.

Irawan, D.M., Kristiana I., dan Aditia M.A.S. 2006. Studi Perbandingan Kualitas Gelatin dari Limbah Kulit Ikan Tuna (Thunnus Spp.), Kulit Ikan Pari (Dasyatis Sp.) dan Tulang Ikan Hiu (Carcarias Sp.) Sebagai Alternatif Penyedia Gelatin Halal. Laporan PKMP-3-12-1. Malang: Fakultas Perikanan, Universitas Brawijaya.

Jannah, A. 2007. Pembuatan Gelatin Halal dari Tulang Ikan Bandeng (Chanos- chanos Forskal) (Sebagai Alternatif Pembuatan Gelatin Halal), Laporan Penelitian, Malang: LEMLIT UIN Malang.

Junianto, Haetami K., dan Maulina I. 2006. Produksi Gelatin dari Tulang Ikan dan Pemanfaatannya Sebagai Bahan Dasar Pembuatan Kapsul. Laporan Penelitian Hibah Bersaing IV Tahun I. Padjadjaran: Fakultas Perikanan dan Kelautan Universitas Padjadjaran.

Karim, A.A. dan Bhat, R. 2009. Fish Gelatin: Properties, Challenges, and Prospects as an Alternative to Mammalian Gelatins. J. Food Hydrocolloids. 23:563-576.
Karlina, I.R. dan Atmaja L. 2010. Ekstraksi Gelatin dari Tulang Rawan Ikan Pari (Himantura Gerarrdi) pada Variasi Larutan Asam untuk Perendaman. [Skripsi]. Surabaya: Jurusan Kimia, FMIPA Institut Teknologi Sepuluh Nopember.

Kurniawan, T. 2009. Aplikasi Gelatin Tulang Ikan Kakap Merah (Lutjanus Sp) pada Pembuatan Permen Jelly. [Skripsi]. Bogor: Program Studi Teknologi Hasil Perikanan, Fakultas Perikanan Dan IImu Kelautan IPB.

Prihardhani, D. I., dan Yunianta. 2015. Ekstraksi Gelatin Kulit Ikan Lencam (Lethrinus Sp) dan Aplikasinya untuk Produk Permen Jeli. Jurnal Pangan dan Agroindustri. 4(1) : 356-366.

Putri, R.W. 2013. Pengaruh Lama Perendaman dan Konsentrasi Asam Klorida Terhadap Kualitas Gelatin dari Tulang Ikan Anggoli (Pristipomoides multidens). [Skripsi]. Malang: Jurusan Teknologi Industri Pertanian Fakultas Teknologi Pertanian Universitas Brawijaya.

Santoso, A.W. 2001. Pengaruh Perbedaan Konsentrasi Asam Klorida dan Lama Perendaman Terhadap Kualitas Gelatin yang Dihasilkan dari Limbah Kulit Belahan (split leather waste). [Skripsi]. Bogor: Jurusan Ilmu Produksi Ternak. Fakultas Peternakan. IPB.

Schrieber, R. dan Gareis, H. 2007. Gelatine Handbook : Theory and Industrial Practice. Wiley-VCH. Weinheim.

Tazwir., Ayudiarti D.L., dan Peranginangin R. 2007. Optimasi Pembuatan Gelatin dari Tulang Ikan Kaci-Kaci (Plectorhynchus chaetodonoides Lac.) Menggunakan Berbagai Konsentrasi Asam dan Waktu Ekstraksi. Jurnal Pascapanen dan Bioteknologi Kelautan dan Perikanan. 2(1) : 35-43. 
Wulandari., Supriadi A., dan Purwanto B. 2013. Pengaruh Defatting dan Suhu Ekstraksi Terhadap Karakteristik Fisik Gelatin Tulang Ikan Gabus (Channa Striata). Program Studi Hasil Perikanan Fakultas Pertanian Universitas Sriwijaya. 2(1) : 38-45. 